

\section{HARVARD UNIVERSITY.}

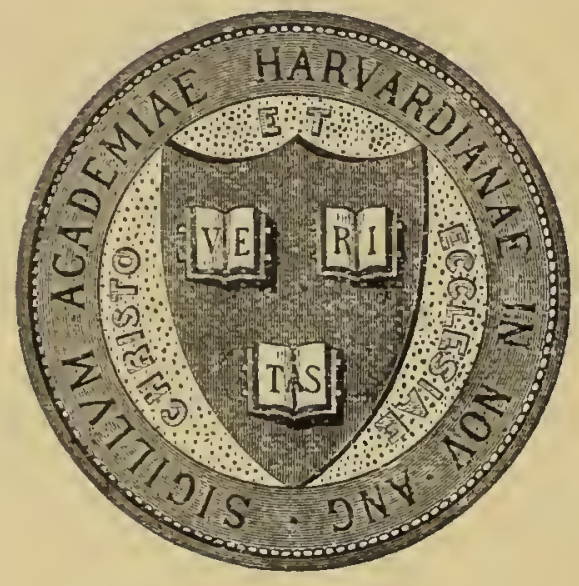

\section{LIBRARY}

OF THE

MUSEUM OF COMPARATIVE ZOÖLOGY $58.38^{4} 1$

Bequest OF

WALTER FAXON

Samuany 14. 1922 
LIST OF BIRUS OBSERVEO ON LONG ISLAND,

$1912-13$.

BY

ROY LATHAM.

LONG ISLAND AGRONOMIST, VOL.VI. NO.12. MEQFORO, N.Y.: JUNE 1,1913 . 


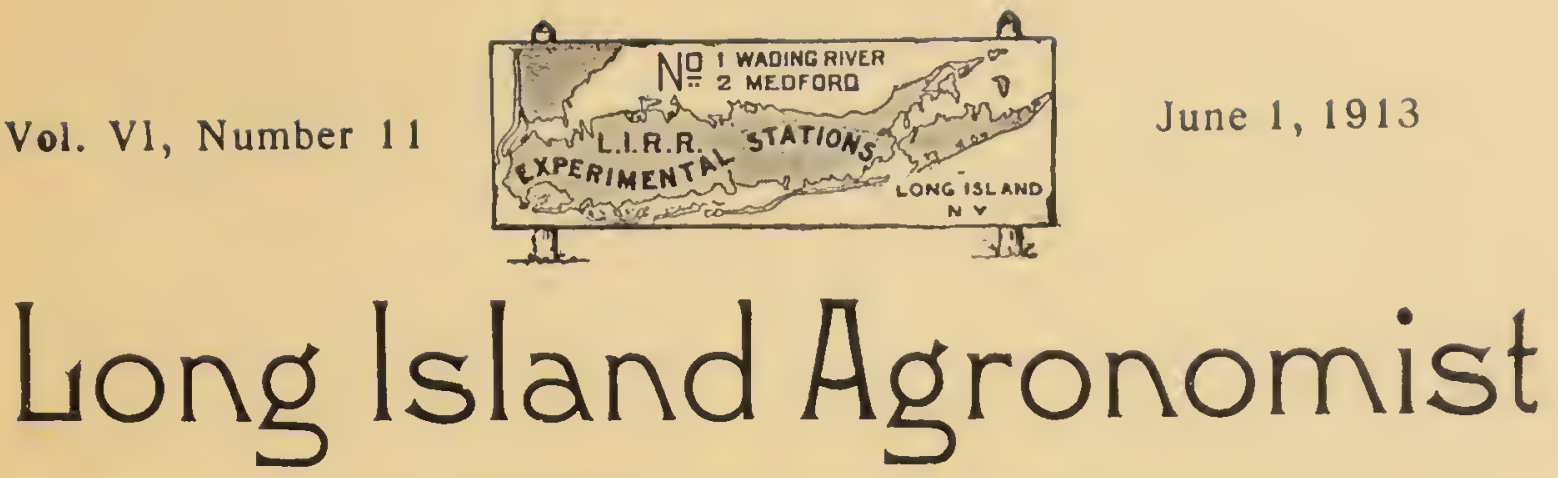

\author{
A Monthly Record of Facts \\ Together With Deductions Based Upon Natures Practical Demonstrations \\ Compiled by Hal. B. and Edith Loring Fullerton \\ Publication Office, Medford, Long Island, New York
}

cover of soy beans.

Rhubarb, set out in the Fall of 1911, up to May 12th this year, has given us a net return of $\$ 207.39$ per aere. 7861 bunches, eontaining four stalks each, have been eut and the plants at the time of writing promise a further crop of fifteen to twenty per cent., the price running from 6 eent a buneh to 21 -4 eents.

Asparagus, which we franlkly confess we have not learned how to handle to obtain the very best results, has of course, because of erratic weather and practieally universally eold nights, not yet reached anywhere near the maximum y ield, but has given us for the acre $\$ 68.90$, yielding 186 bunehes selling from 25 ets. a buneh down to 15 ets., with five or six weeks of cutting still to be credited.

Here then are most assuredly worth-while early in eome yielders which have been handled on the limited aeres at Experimental Station Number Two, Medford, Long Island, in time that eould be spared from planting a market garden with a very complete line of vegetables, the planting of eorn for our little dairy herd silo, care of a mixed fruit orchard, a very extensive test of grapes, bush and vine fruits, an acre of sugar beets, a test for comparison of various fertilizing materials, with the constant interruption of all hands beeause of the fact that visitors are of daily occurence and the office work, with its many ineidentals, oecupy a very eonsiderable portion of oul waking hours.

\title{
OUR BIRDS
}

From Long Island's best posted bird lover, Nelghbor Roy Latham of Orient, we have received a wonderfully complete reeord of those birds which wintered with us. Neighbor Latham's records for twelve years show that 125 speeles of birds have been with us in the Winter time, while during the four seasons, $25 \%$ species have made the Blessed Island their happy home. Here follows neighbor Latham's list with explanatory paragraphs.

The flrst list following is a record of the birds that have been personally observed on Long Island during the Winter 1912-13, between Deeember 20 and February 20. The season being exceptionally mild prior to February there has resulted a marked absence of far Northern species that usually abide with us regularly.

In this list "Resident" denotes birds that live on Long Island thrnughout the year, and except in rare instanees breed here. "Visitant" signifies Northern breeding speeies that are Wintering here. The dates given are the earliest and latest date for thelp departure Northward. In the seeond list below rare and irregular speeies are omitted.

"Summer resident" is a bird that arrives from the South in Spring, spends the Summer with us and returns South in Autumn. Earliest and latest dates for first ones seen are given. "'Transient" is a speeies observed en route between its Winter home in Southern elimes and ita nesting ground in the North. Earliest and latest dates for first ones recorded are given, and in various eases, earliest and latest dates of last one seen are stated. Names given in braekets are loeal names eommonly applied. On various sections of the Island observations will differ, partieularly is this true of ducks, geese and waders.

List of birds observed on Long Island, 1912-13:

Horned Grebe-(Dipper) (IIell Diver), Visitant, May 1 to 15.

Loon-Visitant, June 1 to 20.

Red-throated Loon-Visitant.

Great Black-backed Gull-Visitant March, 18 to 31. 
If you are not a member of the grange in your community you will have just time enough to get in your application and be received into the local grange, to entitle you to membership in the Pomona and so give you the benefits of the next meeting.

The LONG ISLAND AGRICULTURAL UNIVERSITY bill has been passed at Albany and sufficient funds to start the greatest of United States educational institutions devoted to the PARAMOUNT PROFESSION are appropriated.

\section{TRANSPORTATION CURIOS}

Uncle Sam charges 11 cts. to carry one dozen eggs from the producer to the consumer three zones away, while the much hounded railroad carrits the same dozen eggs half way across the continent for two cents a dozen. These unobtrusive little comparisons furnish real educational food for us.

\section{COMIC OPERA SEASON}




\section{EARLY INCOME YIELDERS}

In order to practically demonstrate thc advisability of something besldes "out go" in the Spring of the year we decided to add Fall planted spinach to our other Spring money makcrs, asparagus and rlubarb. We used seed said to be Victoria, as this we found to be thc very best variety of spinach. It received strictly normal attention by way of cultivation and light mulching. It came through the Winter in fine shapc although it showed temporary ill effects caused by the sudden change from a warm Winter to a few weeks of cold in February. One light cultivation with a Planct Jr. hand wheel hoe eounteracted any injury it may have received and we found on close examination ilrot instead of a clean strain of Victoria we had somc Victoria and a job lot of assorted strains known and unknown. Judging as far as we comli cstimate, the y.ioid was fully 20 per cent. under normal yield of Victoria. We cut 458 bushels to the acre. We sold it at an average price of 61 cents a bushel, nur net raturns being $\$ 215.12$ to the acre. As this spinael was raised in our orchard, intercropped by gooseberries, (which of course reduced to a eonsiderable extent the ground occupied by the erop) we were mightily pleased with the returns, having found spinaeh a mighty good Wintcr eover crop to follow our Summer cover of soy beans.

Rhubarb, set out in the Fall of 1911, up to Nray 12th this year, has given us a net return of $\$ 207.39$ per acre. 7861 bunehes, eontaining four stalks eaeh, havc been cut and the plants at the time of writing promise a further crop of fifteen to twenty per cent., the priee running from 6 cent a buneh to $21-4$ cents.

Asparagus, which we frankly confess we have not learned how to handle to obtain the very best resulta, has of course, beeause of erratic weather and practieally universally cold nights, not yet reaehed anywhere near the maximum yield, but has given us for the acre $\$ 68.90$, yielding 186 bunches selling from $25 \mathrm{cts}$. a buneh down to $15 \mathrm{cts}$., with five or six weeks of cutting still to be credited.

Here then are most assuredly worth-while early income yielders which have been handled on the limited acres at Experimental Station Number Two, Medford, Long Island, in time that eould be spared from planting a market garden with a very complete line of vegetables, the planting of corn for our little dairy herd silo, care of a mixed fruit orehard, a very extensive test of grapes, bush and vine fruits, an aere of sugar beets, a test for eomparison of various fertilizing materials, with the constant interruption of all hands because of the faet that visitors are of daily occurence and the office work, with its many incidentals, occupy a very eonsiderable portion of our waking hours.

\section{OUR BIRDS}

From Long Island's best posted bird lover, Neighbor Roy Latham of Orient, we have received a wonderfully complete record of those birds whieh wintered with us. Neighbor Latham's reeords for twelve years show that 125 specles of birds have been with us in the Winter time, while during the four seasons, $25 \%$ species have made the Blessed Island their happy home. Here follows neighbor Latham's list with explanatory paragraphs.

The flrst list following is a record of the birds that have been personally observed on Long Island during the Winter 1912-13, between December 20 and February 20. The season being exceptionally mild prior to February there has resulted a marked absence of far Northern specits that usually abide with us regularly.

In this list "Resident" denotes birds that live on Long Island thrnughout the year, and except in rare instances breed liere. "Visitant" signifies Northern breeding species that arc Wintering liere. The dates given are thc earliest and latest date for their departure Northward. In the second list below rarc and irregular species are omitted.

"Summer resident" is a bird that arrives from the South in Spring, spends the Summer with us and returns South in Autumn. Farliest and latest dates for first ones seen are given. "Transient" is a species observed en route betwcen its Winter home in Southern climcs and its nesting ground in the North. Earliest and latest dates for first ones recorded are given, and in various cases, earliest and latest dates of last one secn arc stated. Names given in brackets are local names commonly applied. On various sections of the Island observations will differ, particularly is this true of ducks, geese and wader's.

List of birds observed on Long Island, 1912-13;

Horned Grebe-(Dipper) (Hell Diver), Visitant, May 1 to 15.

Loon-Visitant, June 1 to 20.

Red-throated Loon-Visitant.

Great Black-backed Gull-Visitant March, 18 to 31. 
Herring Gull-(Sea Gull), Visitant. Rare in summer.

Bonaparte's Gull-Visitant.

Red-breasted Merganser-(Shell drake), common visitant, May 15 to Jan. 10.

Mallard-Rare visitant.

Black Duck-Resident.

Redhead-Visitant.

Scaup-(Broadbill), visitant,

Golden eye-(Whistler), visitant.

Buffle-head-(Butter ball), visitant,

Cld-Equaw--A bundant visitant, May 1 to 15 .

Scooter-Visitant.

White-winged Scooter-(Coot), common visitant

Surf Scooter-(Rock Coot), visitant.

Cancda Gonse--Visitant.

Brant-Visitant.

Bob-white-(Quail), Resident.

Marsh Hawk-(Hen Hawk), rare resident.

Sharp-shinned Hawk-(Chicken Hawk), visitant, May 20 to $\mathbf{8 0}$.

Cooper's Hawk-Visitant.

Red-tailed Hawk-(Hen Hawk), resident.

Red-shouldered Hawk-(Hen Hawk).

Bald Eagle-Visitant.

Sparrow Hawk-Rare resident.

Short-eared Owl-Visitant.

Screech Owl-Resident.

Kingfisher-Resident-Rare in Winter.

Downy Woodpecker-Resident.

Flicker-(High-hole), Resident.

Horned Lark-Abundant visitant, April 20 to May 6.

Blue Jay-Resident.

Crow-Resident.

Fish Crow-Resident.

Starling-This introduced species is now a common resident as far East as Orient Point and is occasionally observed in flocks numbering thousands of individuals.

Redwing-Summer resident.

Neadow lark-Common resident.

Rusty Blackbird-V isitant.

Purple Grackle-(Crow Blackbird).

Goldfinch-Resident.

Pine Siskin-Visitant, Aprii 20 to 30.

Snow Bunting-Visitant, March 1 to 28.

Savannah Sparrow, Transient.

Tree Sparrow-Visitant. March 20 to 30.

Junco-Visitant, April 20 to 30.

Song Sparrow-Resident, abundant.

Swamp Sparrow-Resident, rare.

Fox Sparrow-Transient, visitant.

Cedar Waxwing-Resident.

Northern Shrike-Visitant, rare.

Mjrtle Warble-Common visitant, May 15 to 16.

Pipit-Visitant and transient.

Carolina Wren-Resident.

Winter Wren-Visitant, April 1 to 15.

Brown Creeper-Visilant, A pril 12 to May 4.

White-breasted Nuthatch-Resident.

Chickadee-Resident.

Golden-crowned Kinglet-Visitant, April 10 to 26.

Hermit Tarush-Rare visitant in Winter, common transient.

Robin-Resident.

Ruffed Grouse should be added as it is a permanent resident on the Island.

The pheasant is becoming locally established and of course, the English Sparrow is always present throughout country and town.

$A$ list of Summer residents and transients with data of their appearance from South:

Common Tern-Summer resident, May 15 to 26.

Double-crested Cormorant-(Indian Goose) (Nigger Goose) common transient, March 25 to April 10, June 1 to 10. Rare in Summer. 
Canada Gooso-(Wild Goose) translent, February 22 to March 10, Aprll 20 to May 1. Rare in Winter.

Bittern-Transient, A pril 1 to 15, May 1 to 10.

Least Bittern-Summer resident on Western end of Island, rare visitant at Eastern end.

Great Blue Heron-(Crane) rare permanent resident, more common transient, April 1 to 10.

Green Heron-(Shy-polke) common Summer resident, A pril 15 to May 1.

Black Crowned Night Heron-(Quawk), Summer resident, Narch 24 to 30. Casually in Winter.

Clapper Rail-(Meadow Hen) common Summer resident at Western part of Island. Nay 1 to 10.

Virginia Rail-Summer resident, April 20 to 30.

Woodcock-Rare Summer resident, less rare transient, March 10 to 20 . Recorded in Winter.

Wilson's Snipe-Transient, March 10 to 20. May 1 to 10 . Rare in Winter.

Least Sandpiper-Transient, April 30 to May 10, June 1 to 15.

Yellow-legs-Transient, April 25 to May 20.

Greater Yellow-legs-Transient, April 6 to 25, May 20 to June 10.

Solitary Sandpiper-Transient, May 1 to 12, May 15 to 30.

Spotted Sandpiper-Summer resident, April 20 to 30.

Black-bellied Plover-(Grey Plover), transient, Nay 1 to June 10.

Killdeer-Rare transient, March 1 to April 16.

Semipalma ted Plover-Transient, May 20 to June 1.

Piping Plover-Summer resident, April 1 to 10.

Turnstone-Common transient, May 12 to 16 , June 1 to 12.

Mourning Dove-Summer resident, March 10 to 20.

Turkey Vulture-Rare visitant, May 3 to 20.

Osprey-(Fish Hawk), Summer resident, March 15 to 28.

Yellow-billed Cuckoo-Summer resident. May 10 to 25.

Black-billed Cuckoo-Summer resident, May 10 to 20.

Kingfisher-Resident, migrant birds arrive March 20 to 30.

Yellow-billed Sapsucker-Transient, April 1 to 15.

Whip-poor-will-Summer resident, April 28 to May 5.

Nighthawk-(Mosquito Hawk), Summer resident, May 1 to 10.

Chimney Swift-(Chimney swallow), Summer resident, April 21 to MIay 10.

Ruby-throated Hummingbird-Summer resident, May 1 to 10.

King bird-Summer resident, April 28 to May 5.

Crested Flycatcher-Summer resident

Phoebe-Locally common, Summer resident, March 10 to 20.

Wood Pewee-Summer resident, May 10 to 22.

Least Flycatcher, Summer resident, local, May 1 to 12.

Bobolink-Summer resident, May 1 to 10 .

Cowbird-(Lazybird), common Summer resident, February 28 to March 10.

Red-winged Blackbird-Common Summer resident. Often seen in Winter. February 22 to March 12.

It is the greyish striped female of this species that is so often termed "skunk black-bird." The scarlet shouldered mate being frequently called "swamp blackbird" locally.

Orchard Oriole-Summer resident, May 1 to 10.

Baltimore Oriole-(Hanging-bird) (Golden Robin), common Sumner resident, May 1 to 15 .

Purple Grackle-(Crow Blackbird), abundant Summer resident, February 25 to March 12. Often observed in Winter. 
Purple Finch-Rare visitant, March to May.

Vesper Sparrow-Summer resident, March 28 to A pril 10.

Savannah Sparrow-Rare resident, common transient, March 30 to Aprll 10.

Grasshopper Sparrow-Summer resident, April 20 to 30

Sharp-tailed Sparrow-Abundant Summer resident on the salt meadows, April 15 to May 1.

Sea-side Sparrow-Summer resident, April 20 to 30.

White-crowned Sparrow-Transient, rare, April 10 to 30, May 16 to 30.

White-throated Sparrow-Not common Winter visitant, common translent, A pril 1 to 15 , May 15 to 22.

Chipping Sparrow-Abundant Summer resident, April 4 to 10.

Fox Sparrow-Transient, February 25 to March 20, April 1 to 10.

Towhee-Summer resident, A pril 25 to May 5.

Rose-breasted Grosbea.k-Rare transient and Summer resident, May 1 to 15.

Indigo Bunting-Summer resident, May 1 to 10.

Scarlet Tanager-Summer resident, May 1 to 12.

Purple Martin-Summer resident, local. A pril 4 to May 7.

Barn Swallow-Abundant Summer resident, April 9 to 20.

Tree Swallow-(White bellied Sparrow), rare Summer resident, abundant transient, March 16 to April 1.

Bank Swallow-Summer resident, A pril 28 to May 10.

Red-eyed Vireo-Common Summer resident, May 1 to 10.

Yellow-throated Vireo-Not common Summer resident, May 4 to 12.

Blue-headed Vireo-Transient, April 20 to MIay 20.

White-eyed Vireo-Summer resident, May 10 to 20.

Black-and-White Warbler-Summer resident, April 20 to May 1.

Worm-eating Warbler-Rare transient, April 28 to May 4.

Blue-winged Warbler-Locally a Summer resident, Nay 1 to 10.

Nashville Warbler-Transient, May 10 to 15, May 22.

Parula Warbler-Summer resident locally, April 28 to May 10.

Cape May Warbler-Transient, May 10 to 15.

Yellow Warbler-(Yellow-bird) Summer resident, common, May 1 to 5.

Black-throated Blue Warbler-Transient, May 1 to 12, May 15 to 23.

Magnolia Warbler-Transient, Nay 4 to 10, May 20 to 25.

Chestnut-sided Warbler-Transient, Nay 2 to 10 , May 15 to 26 .

BaJ-breasted Warbler-Transient, May 15 to 25.

Black-poll Warbler-Transient, May 8 to 15, May 28 to June 15.

Blackburnian Warbler-Transient, May 4 to 15, May 15 to 22.

Black-throated Green Warbler-Common transient, also a rare Summer resident, A pril 28 to May 1.

Pine Warbler-Summer resident, March 28 to A pril 10.

Yellow Palm Warbler-Transient, A pril 10 to 15, May 1 to 15.

Prairie Warbler-Lacally a Summar resident, May 1 to 10.

Oven-bird-Summer resident, May 1 to 12.

Water Thrush-Transient, May 1 to 10 . Nay 20 to 30 .

Yellow-throat-A bundant Summer resident, May 1 to 8

Yellow-breasted Chat-Summer resident, May 10 to 15.

Canadian Warbler-Transient, May 10 to 15.

Redstart-Summer resident, NIay 1 to 12.

Pipit-Transient, often Winters, April 1 to 15, May 1 to 16.

Catbird-Common Summer resident, April 28 to Mlay 5.

Brown Thrasher-Summer resident, April 28 to Nay 10.

House Wren-Summer resident, A pril 20 to 28.

Ruby-crowned Kinglet-Transient, April 20 to May 20.

Wood Thrush-Summer resident, Nay 1 to 10.

Wilson's Thrush-Rare Summer resident, more common migrant, May 1 to 15 .

Hermit Thrush-Common transient, rare Winter visitant, A pril 10 to 20, April 20 to 28.

Robin-Rather common, permanent resident, not regular in Winter. Arrival of migrants February 23 to March 10.

Bluebird-Summer resident, rare in Winter, March 1 to 5. 




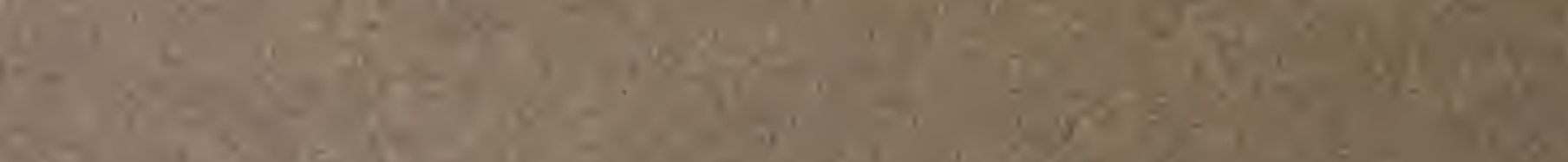

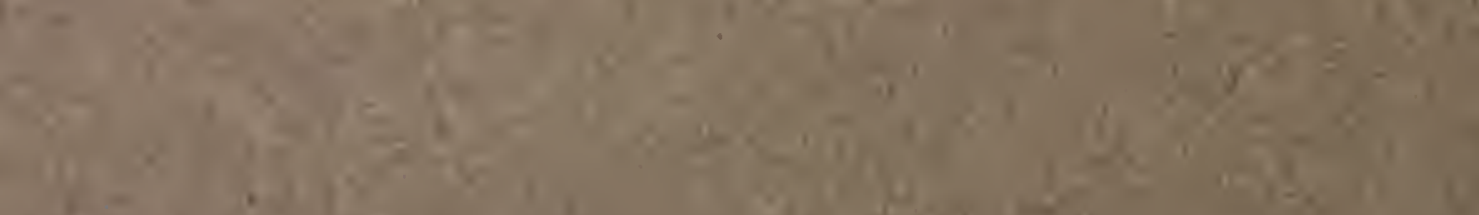

.

20

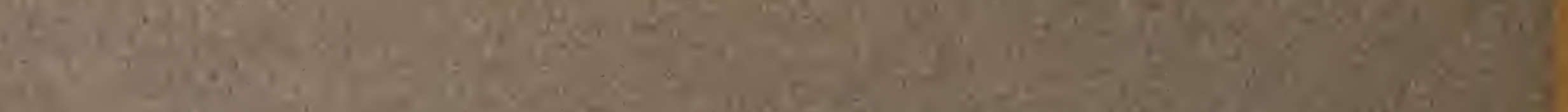

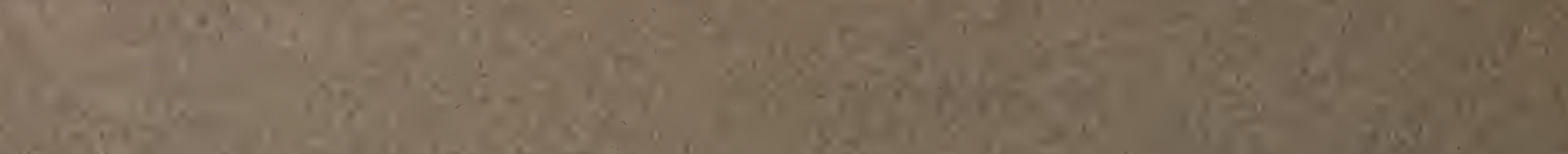

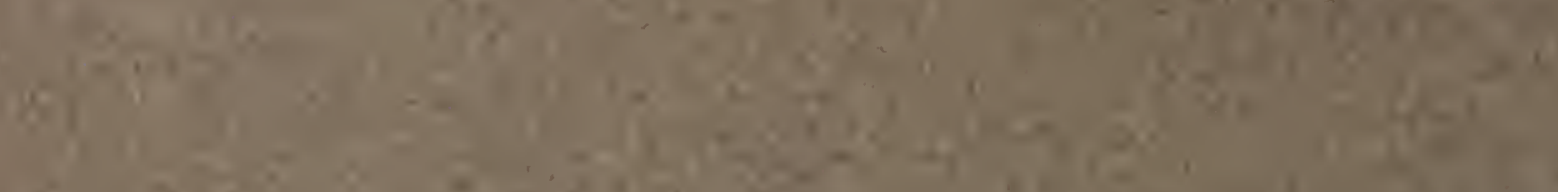

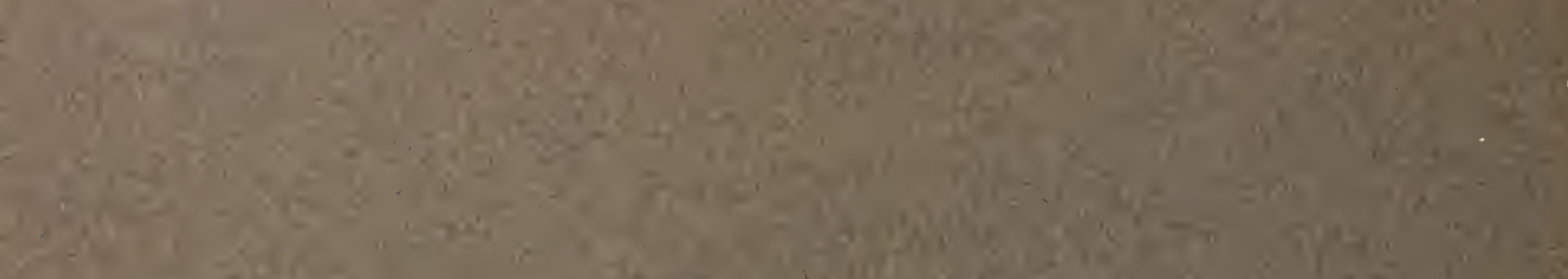

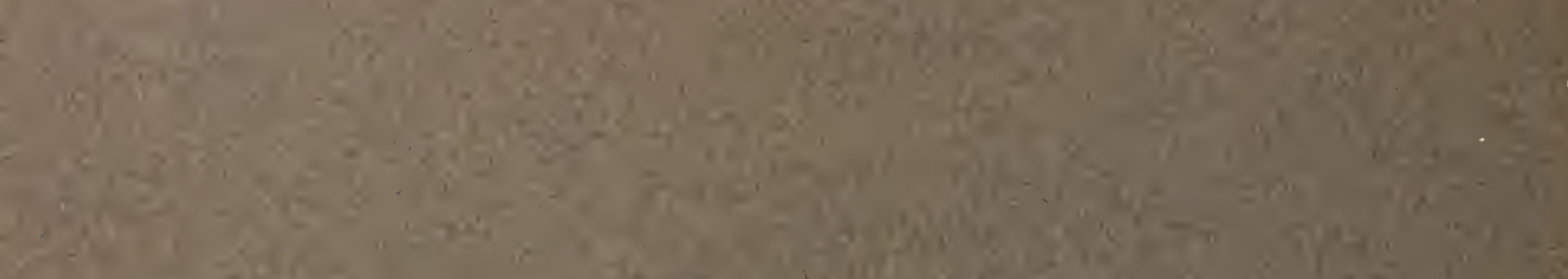

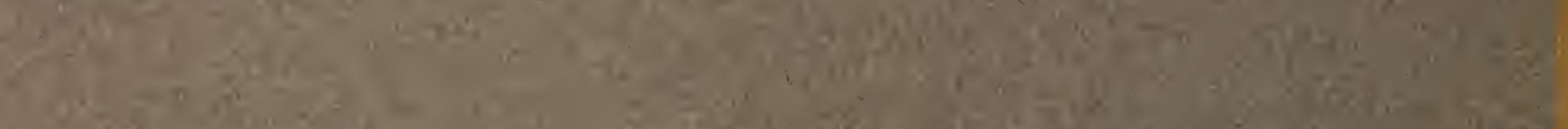

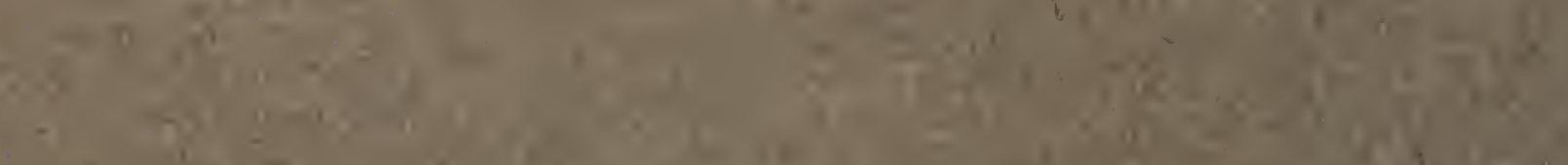

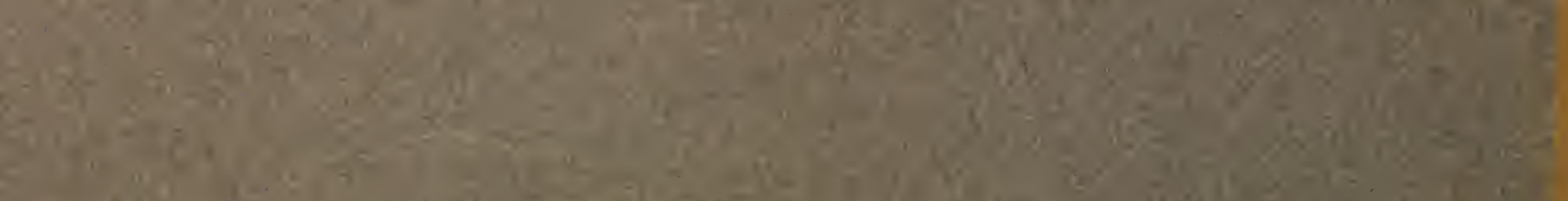

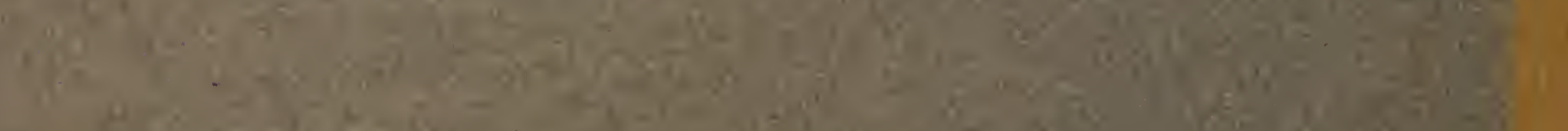

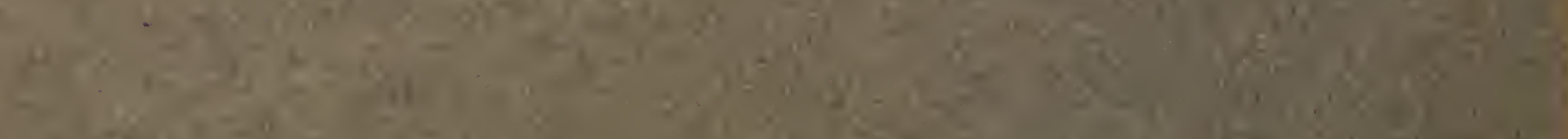

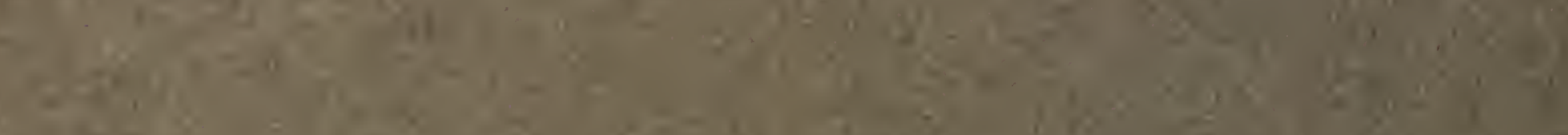

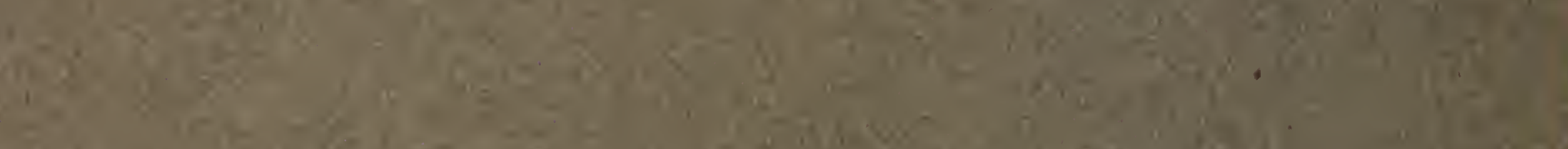

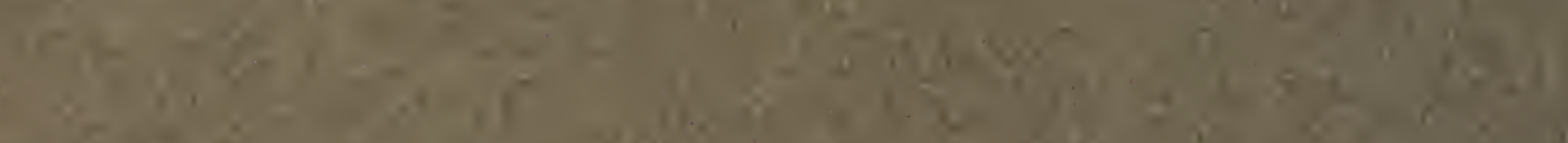

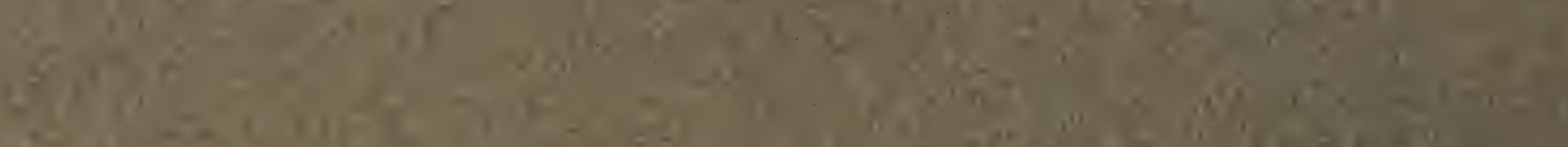

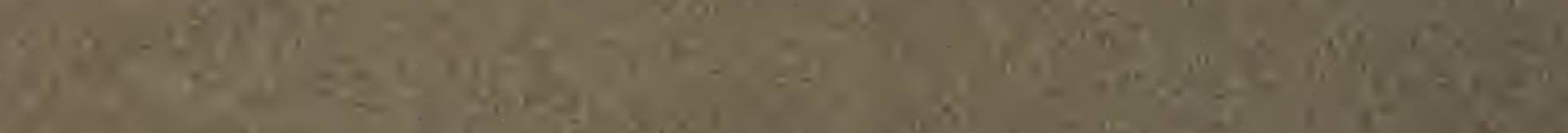

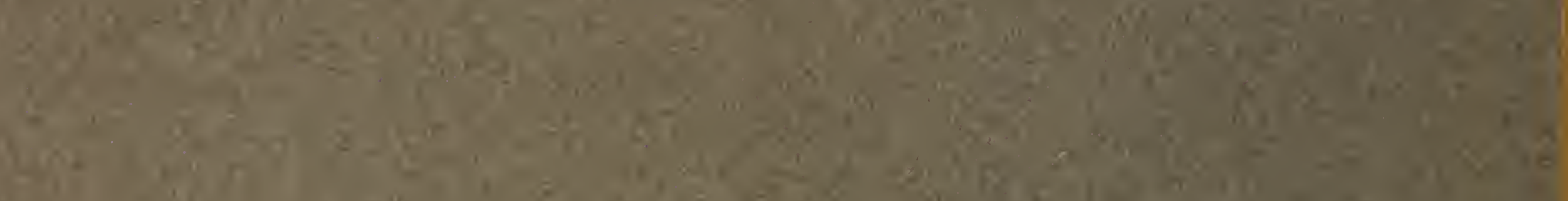

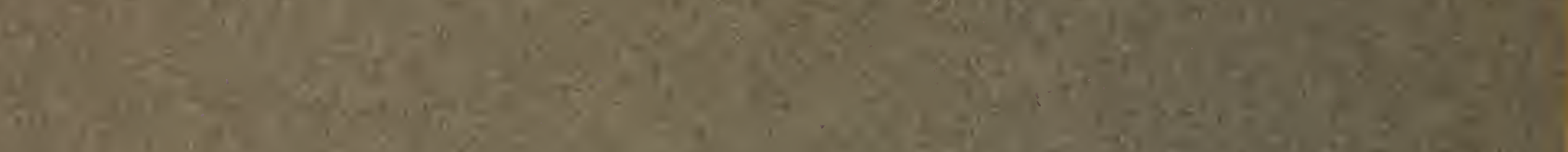

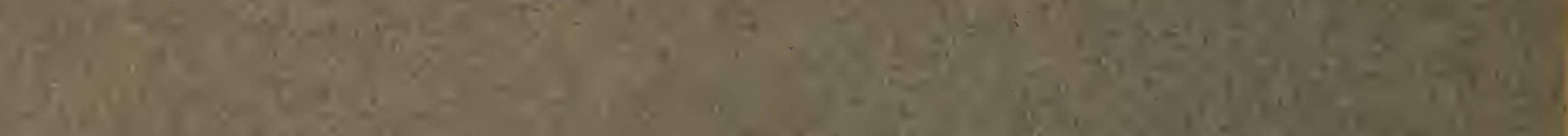

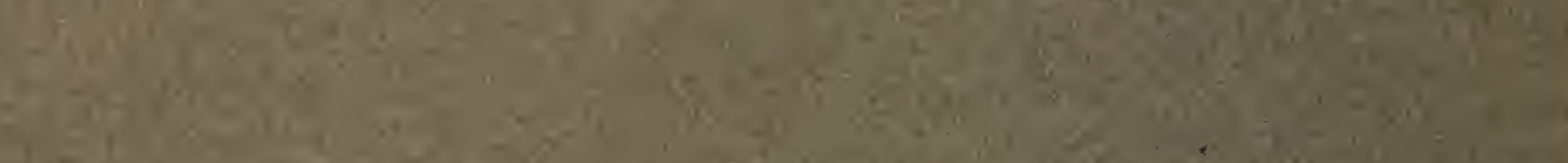

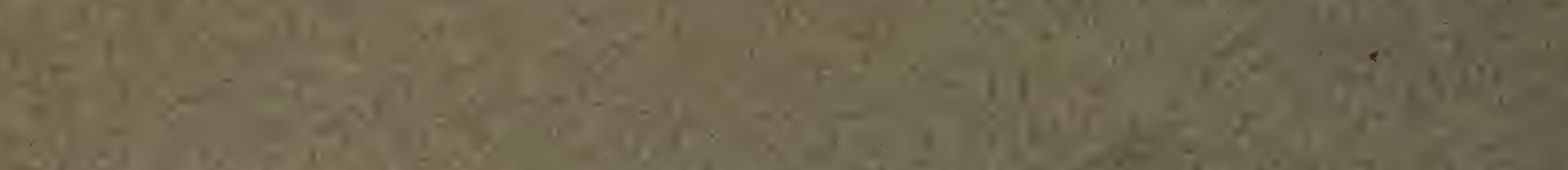

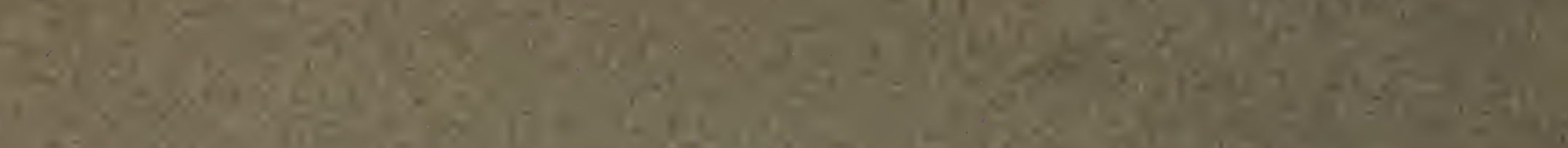

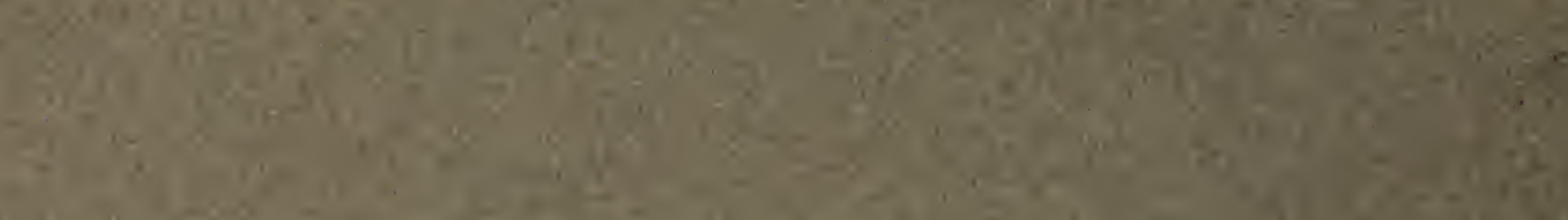

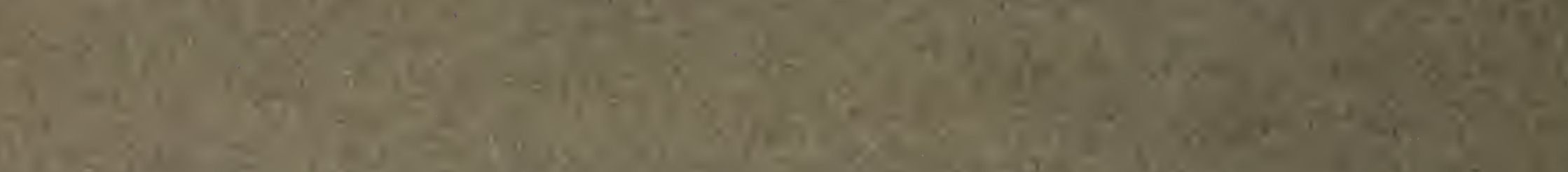

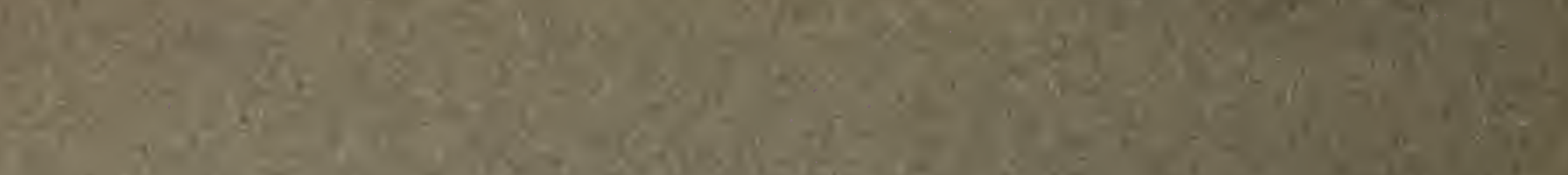

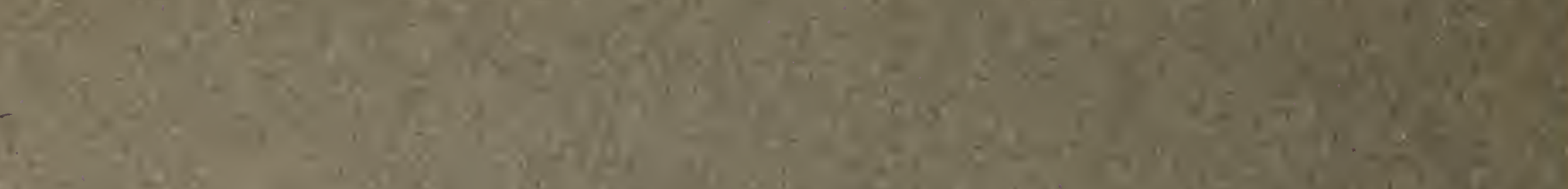

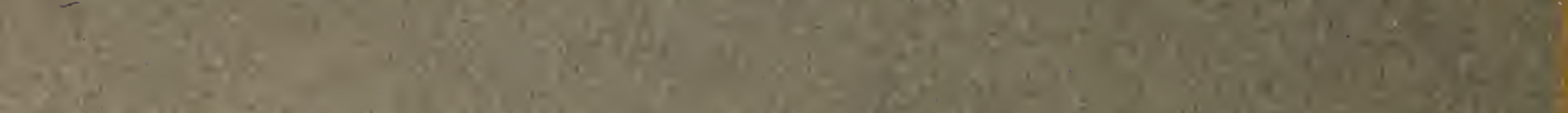

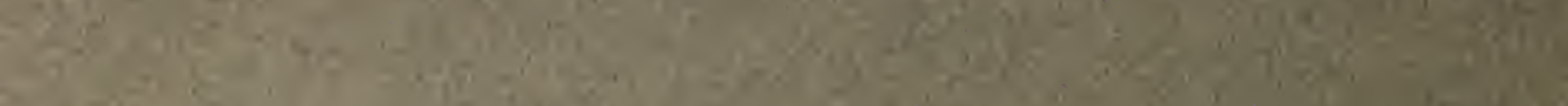

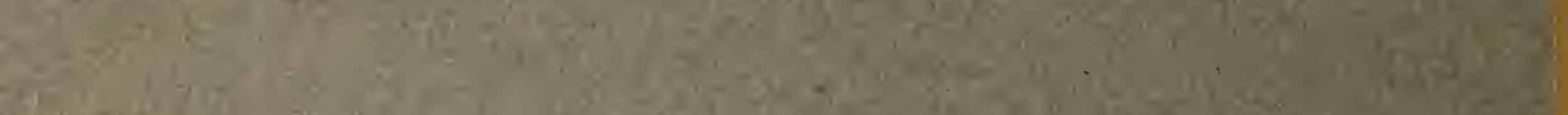

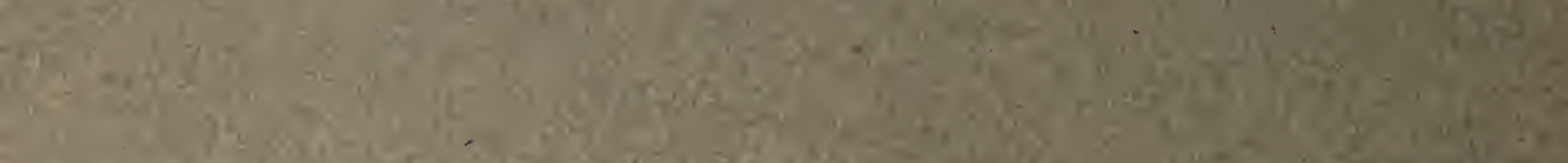

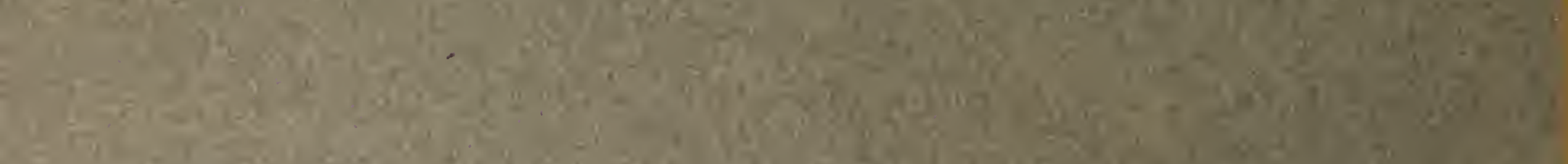

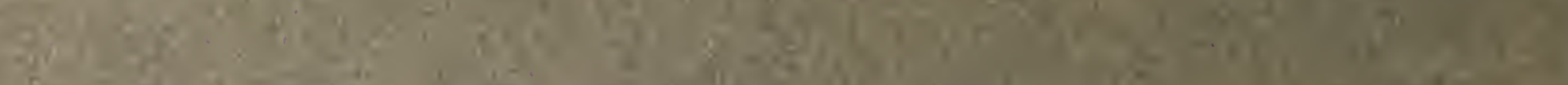

